\title{
Огранка «овал» для ювелирной вставки из муассанита
}

\author{
Петров О.П., студент, \\ Северо-Восточный федеральный университет, \\ 2. Якутск \\ E-mail: morza.style@inbox.ru
}

Научный руководитель: к.т.н., доцент Федотова М.А.

В конце XX века в США на рынке драгоценных камней и ювелирных изделий появился новый камень, а точнее синтетический кристалл карбида кремния (муассанит). Так как муассанит по своим физическим характеристикам очень близок к алмазу, то его ввели изначально на рынок как имитацию бриллианта, но пришло время изменить ситуацию. Муассанит достоин признания в качестве самостоятельного ювелирного камня.

Муассанит (карбид кремния) был впервые найден на месте падения метеорита в каньоне Diablo (Аризона). В природе такой минерал встречается крайне редко и в ничтожно малых количествах. По таким ювелирным качествам, как игра, прозрачность и бесцветность, муассанит превосходит многие драгоценные камни и уступает только алмазу в твердости и плотности. Алмаз по шкале Мооса имеет твердость 10, а муассанит - 9.25. Коэффициент преломления (основной показатель, обеспечивающий игру камня) у муассанита 2,65 выше, чем у алмаза 2,42. Блеск муассанита, твердость, вес и сопротивление царапинам конкурируют со всеми другими драгоценными камнями. Соответственно, муассанит является одним из лучших камней в ювелирных целях.

Целью данной работы является выбор вида огранки для образцов синтетического муассанита, представленных нам научно-исследовательским институтом Korea Institute of Ceramics Engineering Technologies (KICET). Пионером ювелирного муассанита считается компания из Северной Каролины США CREE, которая в 1980-х годах разработала промышленный процесс синтеза крупных монокристаллов карбида кремния. Летом 1995 г. Опытные образцы муассанита прошли огранку у специалистов по бриллиантам и получили у них высокую оценку. К ювелирному проекту подключилась американская компания Charles \& Colvard, которая в настоящее время является практически эксклюзивным производителем ювелирного муассанита [2]. У этой компании разработана некая эксклюзивная огранка для муассанита, заключающаяся в изменении параметров бриллиантовой огранки КР-57. Но вряд ли стоит применять бриллиантовую огранку для муассанита. Данная бриллиантовая огранка была разработана математиком М. Толковским для огранки алмазов (рис. 1).

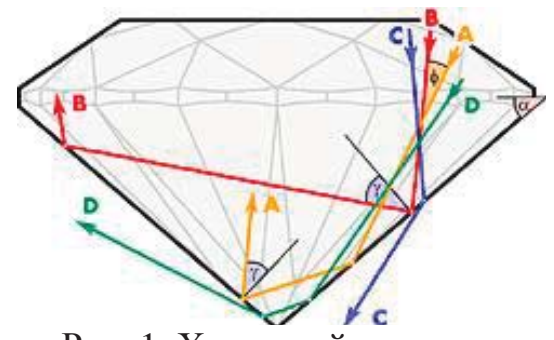

Рис. 1. Ход лучей в бриллианте [1]

Он рассчитал следующую “идеальную" форму огранки бриллианта. Выбрав в качестве стартовой точки простое треугольное сечение, Толковский нашел геометрические и оптические аргументы для доказательства необходимости существования в алмазе центросимметричной круглой бриллиантовой огранки (огранки типа "старая копь") определенного числа специальным образом расположенных граней для того, 
чтобы обеспечить максимальный возврат света. Так он подтвердил "идеальность" этого типа огранки. Толковский [3] ввел "оптическую добротность" (optical goodness) бриллианта как произведение угловой дисперсии красных и синих лучей на коэффициент пропускания зеленых лучей при одном том же угле падения, когда верхняя часть бриллианта имеет высоту 0,144 от величины диаметра камня, диаметр площадки 0,53 диаметра, угол наклона основных граней 40,75. Общая высота бриллианта 0,6 диаметра, а высота рундиста 0,01-0,02 диаметра. Однако с целью экономии сырья алмазы практически никогда не гранят этой идеальной математически рассчитанной огранкой.

Но все же муассанит отличается от природных алмазов и бриллиантов. Основным из отличий является тот факт, что он имеет двупреломление, причем сильное. Если рассматривать кристалл муассанита в любом направлении, не совпадающем с его оптической осью, то заметно раздвоение задних (противоположных) граней и ребер, как это наблюдается, например, у кальцита или у циркона. Но огранщики специально ориентируют муассанит таким образом, что при просмотре камня через площадку раздвоение граней не наблюдается. Однако при некотором повороте камня можно наблюдать раздвоение, например, шипа, или при фокусировке зрения на гранях низа наблюдается раздвоение отражения площадки камня, чего не бывает у бриллианта. И для того, чтобы этого не происходило, нужно, чтобы свет проходил вдоль оптической оси. Другой особенностью внутреннего строения муассанита является то, что в нем наблюдаются включения в виде каналов или игл, которые обычно многочисленны и хорошо видны даже при небольшом увеличении (например, в обычную геммологическую лупу 10x).

Таблица 1

Параметры огранки «овал» [5]

Овал Ов-57

\begin{tabular}{|c|c|c|c|c|}
\hline \multicolumn{5}{|c|}{ Параметры бриллианта } \\
\hline Группа & \multicolumn{3}{|c|}{ A } & Б \\
\hline $\mathbf{n = A / B}$ & \multicolumn{3}{|c|}{$1.20-1.80$} \\
\hline $\begin{array}{c}\text { Масса, } \\
\text { карат }\end{array}$ & до 0.49 & $0.50-0.99$ & от 1.00 & от 0.10 \\
\hline bp, \% & $55-65$ & $55-65$ & $55-65$ & $55-65$ \\
\hline hr, \% & $1.5-3.0$ & $0.7-2.5$ & $0.7-2.5$ & $0.7-3.0$ \\
\hline$\alpha$, град & $30-35$ & $30-35$ & $30-36$ & $30-36$ \\
\hline$\beta$, град & $39-42$ & $39-42$ & $39-42$ & $39-42$ \\
\hline
\end{tabular}

Исходя из этого, лучшим видом огранки для муассанита может послужить огранка формы овал с видоизмененными углами. Этот вид огранки появился относительно недавно, в 1960 году. Такая огранка, имеет ровный овальный контур (табл. 1). Принцип огранки овальной формы такой же, как и у круглой. Отличие в том, что только у «овала» вытянутая форма. Овальная форма имеет прекрасные характеристики дисперсии света и бриллиации. Если сравнивать «овал» с круглой огранкой, то при одинаковом весе, площадка у овальной формы камня больших размеров, поэтому блестит и «играет» овальная огранка как круглая, но выигрывает визуально по размеру [4]. Так как образцы кристалла карбида кремния могут быть довольно крупными, то данная огранка должна идеально подойти. Так как оптические 
характеристики муассанита отличаются от алмаза, то тут следует изменить углы верха с 30 градусов до 26, а галстук уменьшить до 70\%, и сделать некоторые поправки, чтобы получить полное внутреннее отражение света в камне. К тому же это еще должно помочь избежать двупреломления в камне.

Таким образом, мы предлагаем огранить образцы $\mathrm{SiC}$ огранкой формы овал, что выявит наилучшие качества ювелирного камня муассанит.

\title{
Список литературы :
}

1) http://www.gemology.ru/cut/russian/vasiliev/vas1.htm

2) http://www.rough-polished.com/ru/expertise/13927.html

3) http://www.octonus.lgg.ru/cut/russian/_dodson1.htm

4) http://sunlight.net/faq/oval.html

5) http://id77.livejournal.com/1332666.html

\section{Армирование ледовых переправ «Пайкеритом»}

\author{
Тимофеева М.Г., студентка, \\ Северо-Восточный федеральный университет, \\ 2. Якутск \\ E-mail: tmg.95@mail.ru
}

\section{Научный руководитель:} доцент Попов В.Ф.

Большая часть территории нашей страны расположена в северных районах, лишённых развитой дорожной сети. В зимний период для доставки грузов, пассажиров и техники в этих районах широко используются автозимники и ледовые переправы. Так, например, по данным МЧС, ежегодно в России официально действует до 500 ледовых переправ. Отличительные особенности ледовых переправ и автозимников сравнительно малые интенсивность и скорость движения транспортных средств, а также значительная грузоподъёмность большинства автомобилей, осуществляющих грузоперевозки по этим временным дорогам. Для безопасного пропуска большегрузных транспортных средств (общей массой 30ч 40 т и более) требуется толстый прочный ледовый покров (70ч90 см и более) с минимумом трещин. В строительстве ледовых автозимников для их усиления можно использовать всевозможные материалы, например: солому, ветки, пульпу из газетной бумаги, листы пергамента, опилку и т.п. В нормативах ледовые автозимники рекомендуется усиливать намораживанием дополнительных слоёв льда сверху. Для армирования дорожных конструкций «пайкеритом» позволяет повысить их сопротивление растягивающим напряжениям от силовых и температурных воздействий, уменьшить трещинообразование и увеличить срок службы автомобильных дорог. В этом плане, разработка практических рекомендаций и совершенствование технологии по усилению ледового покрова автозимников «пайкеритом» является актуальной научно-технической задачей народного хозяйства страны. 